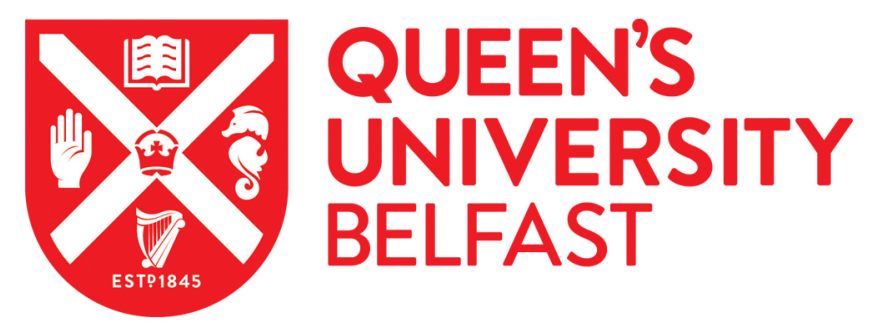

\title{
125 years of BJR and radiological research: reflecting on the anniversary series in celebration of the world's oldest radiology journal
}

Jackson, S. A., \& Prise, K. M. (2020). 125 years of BJR and radiological research: reflecting on the anniversary series in celebration of the world's oldest radiology journal. The British journal of radiology, 94(1117), [bjr20219001]. https://doi.org/10.1259/bjr.20219001

Published in:

The British journal of radiology

Document Version:

Publisher's PDF, also known as Version of record

Queen's University Belfast - Research Portal:

Link to publication record in Queen's University Belfast Research Portal

Publisher rights

(C) 2021 The Authors.

This work is made available online in accordance with the publisher's policies. Please refer to any applicable terms of use of the publisher.

\section{General rights}

Copyright for the publications made accessible via the Queen's University Belfast Research Portal is retained by the author(s) and / or other copyright owners and it is a condition of accessing these publications that users recognise and abide by the legal requirements associated with these rights.

Take down policy

The Research Portal is Queen's institutional repository that provides access to Queen's research output. Every effort has been made to ensure that content in the Research Portal does not infringe any person's rights, or applicable UK laws. If you discover content in the Research Portal that you believe breaches copyright or violates any law, please contact openaccess@qub.ac.uk. 


\title{
BJR $125^{\mathrm{TH}}$ ANNIVERSARY: EDITORIAL
}

\section{5 years of $B J R$ and radiological research: reflecting on the anniversary series in celebration of the world's oldest radiology journal}

\author{
'SIMON A JACKSON and ${ }^{2}$ KEVIN M PRISE \\ ${ }^{1}$ Peninsula Radiology Academy, University Hospitals Plymouth NHS Trust, Plymouth, UK \\ ${ }^{2}$ Patrick G, Johnston Centre for Cancer Research, Queen's University Belfast, Belfast, UK

Throughout 2020, we have celebrated the 125th anniversary of the world's oldest radiology journal, British Journal of Radiology (BJR). As readers will be aware, in recognition of this important milestone, we commissioned and have published a broad range of predominantly modality-based Review articles. These have focussed on looking forward to the challenges and opportunities which lie ahead including key developments in CT, MRI, multimodality imaging, nuclear medicine and molecular imaging, interventional oncology, radiotherapy and tumour immunology, particle therapy, hypoxia, radiomics and quantitative imaging.

The anniversary series launched in January 2020 with an Editorial, " 125 years of radiology research - BJR's history is radiology's history", by Adrian Thomas, Honorary Historian of the British Institute of Radiology (BIR). The Editorial mapped the interesting development of BJR from its origins in 1896 as the Archives of Clinical Skiagraphy to the present day.

This was followed in the February issue of $B J R$ by an insightful "hot topic" Review by Issam El Naqa and colleagues entitled "Artificial Intelligence: reshaping the practice of radiological sciences in the 21 st century". 2 The paper acknowledged the pioneering work of practitioners in the radiological sciences, developing and implementing artificial intelligence (AI) in many areas related to diagnostic imaging and therapy. The article reviewed the current status of AI and reflected on the challenges which need to be overcome in order to fulfil its potential of providing better and more affordable precision health care for both patients and wider society.

In April, we published a Review by Philippe Lambin and colleagues addressing another rapidly developing topic
"Radiomics: from qualitative to quantitative imaging" ${ }^{3}$ This focussed on the challenges surrounding quantification in imaging and how the emerging field of radiomics, whether handcrafted or deep, translates medical images into quantitative data to provide biological information and enable radiologic phenotypic profiling for diagnosis, theragnosis, decision support, and monitoring. And, thus contributing to the emerging era of precision medicine.

The abscopal effect first described in a seminal BJR article published during 1953 by RH Mole ${ }^{4}$, was featured in May with a Review from Sandra Demaria and Silvia Formenti entitled "The abscopal effect 67 years later: from a sidestory to center stage". 5 The article reviewed the history and clinically relevant role of the abscopal effect initiating a systemic immune response and its important impact in the separate fields of radiation therapy and cancer immunology.

In the June issue of $B J R$, Patrick Veit-Haibach and colleagues looked into the arena of nuclear medicine with a Review entitled "Nuclear Medicine and molecular imaging advances in the 21 st century". 6 The paper focussed on the varied radiopharmaceuticals utilised in positron emission tomography, covering dual probe techniques and the impact of theranostic approaches used for the delivery of personalised medicine.

In July, Peter Börnert and David Norris addressed modality based diagnostic imaging with a paper entitled "A half-century of innovation in technology - preparing MRI for the 21st century". Their insightful Review reflected on the development of MRI over the last halfcentury into what is today an indispensable non-ionising medical imaging technique due to excellent soft-tissue contrast resolution and variety of accessible tissue and 
physiological parameters. The future application of AI in MRI was also highlighted.

John Boice and colleagues covered the field of radiation protection in the August issue with a paper entitled "Evolution of radiation protection for medical workers". ${ }^{8}$ This reviewed the evolution of radiation protection over the past century to the present day. Covering advances in new technology and reflecting on the increasing requirement for radiation protection owing to an acceleration in medical radiation uses, paralleled with consideration for the safety of an enlarging medical radiation worker workforce.

Two anniversary Reviews were published in the September issue of BJR. Thomas Helmberger covered "The evolution of interventional oncology in the 21 st century". ${ }^{9}$ He reflected on the developments in the field as well as the synergistic future role interventional techniques will play in the field of immuneoncology. In particular, the possibility of tumour control at the cellular level. In addition, a Review by Griffin and colleagues addressed the important topic of damage to normal tissue arising from high-dose radiotherapy exposures in a paper entitled "History and current perspectives on the biological effects of high-dose spatial fractionation and high dose-rate approaches: GRID, Microbeam \& FLASH radiotherapy". ${ }^{10}$ Specifically, the development of advanced delivery modalities for achieving effective tumour control whilst sparing adjacent tissue at risk.

Juergen Debus and colleagues covered "Particle therapy in the future of precision therapy" 11 in the October issue. This followed on from the $B J R$ special feature on proton therapy published in March 2020. ${ }^{12}$ The Review summarised the important physical and radiobiological characteristics of accelerated charged particles using specific clinical examples of their clinical application.

Figure 1. Simon Jackson

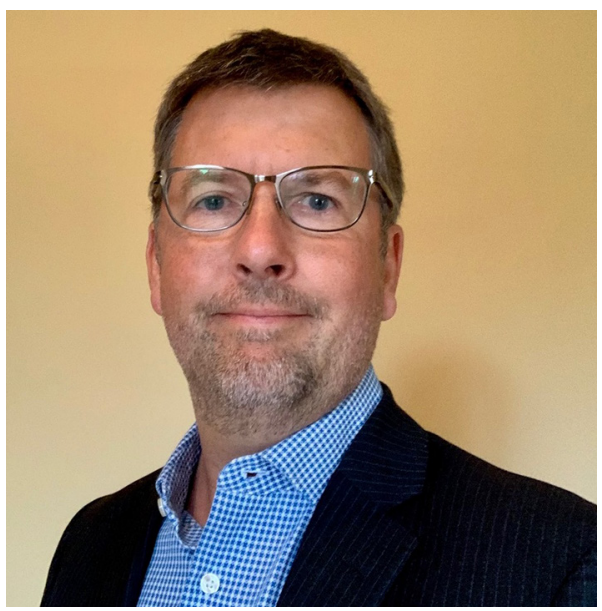

In November, Dow-Mu Koh and colleagues returned to the topic of MRI with a Review entitled "What's new for clinical whole-body MRI (WB-MRI) in the 21 st century" ${ }^{13}$ This highlighted the increasing use of WB-MRI to survey disease across multiple sites and organ systems in the body thus reducing overall population medical radiation exposure. The paper addressed technical improvements in WB-MRI in addition to indications for the technique including disease screening, paediatric imaging as well as oncological and non-oncological applications.

In this issue, we include a comprehensive Review by Lynne Koweek and colleagues entitled "Multimodality Cardiac Imaging in the 21st century: evolution, advances and future directions". ${ }^{14}$ The paper covers key developments in the field over the past 20 years including the increase in hybrid and fusion imaging techniques as well as the incorporation of AI and machine learning into clinical workflows. These advances helping to enhance patient management and clinical outcomes.

In the coming months, we will be publishing the final articles in order to complete the BJR 125th anniversary series. These will include a thought provoking Review by Matthias Prokop addressing the evolution of CT from the seminal paper by Godfrey Hounsfield in $1973^{15}$ to the present day and beyond; and finally, a Review by Jens Overgaard which will highlight the 1953 seminal paper by L.H. Gray et al. ${ }^{16}$ on the impact of tumour hypoxia in radiotherapy and reflecting on the latest developments in the field of translational radiation biology.

During these uncertain times, we very much hope that you have enjoyed reading the articles comprising $B J R$ 125th anniversary series published to date, and we would like to take this opportunity to again personally thank all contributing authors for their time, insight and specialist expertise.

Figure 2. Kevin Prise

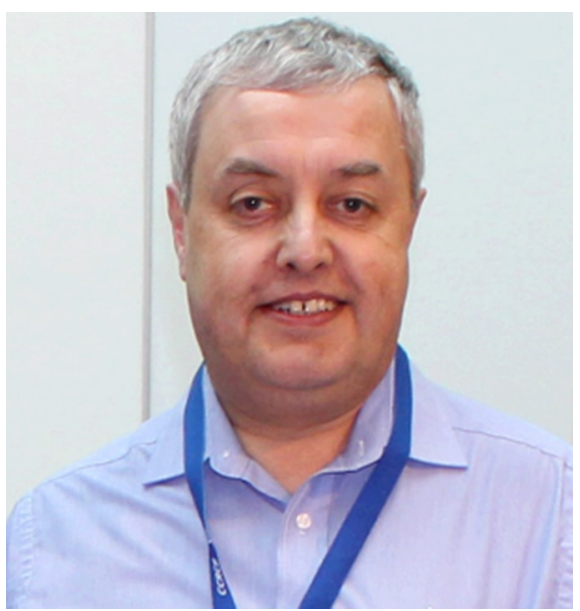




\section{REFERENCES}

1. Thomas A. 125 years of radiological research-BJR's history is radiology's history. Br J Radiol 2020; 93: 20209002 doi: https://doi.org/10.1259/bjr.20209002

2. El Naqa I, Haider MA, Giger ML, Ten Haken RK. Artificial intelligence: reshaping the practice of radiological sciences in the 21 st century. Br J Radiol 2020; 93: 20190855. doi: https://doi.org/ 10.1259/bjr.20190855

3. Rogers W, Thulasi Seetha S, Refaee TAG, Lieverse RIY, Granzier RWY, Ibrahim A, Seetha ST, et al. Radiomics: from qualitative to quantitative imaging. Br J Radiol 2020; 93: 20190948. doi: https://doi.org/10.1259/ bjr. 20190948

4. Mole RH. Whole body irradiation; radiobiology or medicine? Br J Radiol 1953; 26: 234-41. doi: https://doi.org/10.1259/ 0007-1285-26-305-234

5. Demaria S, Formenti SC. The abscopal effect 67 years later: from a side story to center stage. Br J Radiol 2020; 93: 20200042. doi: https://doi.org/10.1259/bjr. 20200042

6. Vaz SC, Oliveira F, Herrmann K, Veit-Haibach P. Nuclear medicine and molecular imaging advances in the 21st century. Br J Radiol 2020; 93:
20200095. doi: https://doi.org/10.1259/bjr. 20200095

7. Börnert P, Norris DG. A half-century of innovation in technology-preparing MRI for the 21st century. Br J Radiol 2020; 93: 20200113. doi: https://doi.org/10.1259/bjr. 20200113

8. Boice J, Dauer LT, Kase KR, Mettler FA, Vetter RJ. Evolution of radiation protection for medical workers. Br J Radiol 2020; 93: 20200282. doi: https://doi.org/10.1259/bjr. 20200282

9. Helmberger $\mathrm{T}$. The evolution of interventional oncology in the 21st century. Br J Radiol 2020; 93 20200112. doi: https://doi.org/10.1259/bjr. 20200112

10. Griffin RJ, Prise KM, McMahon SJ, Zhang $\mathrm{X}$, Penagaricano J, Butterworth KT. History and current perspectives on the biological effects of high-dose spatial fractionation and high dose-rate approaches: GRID, Microbeam \& FLASH radiotherapy. $\mathrm{Br} \mathrm{J}$ Radiol 2020; 93: 20200217. doi: https://doi. org/10.1259/bjr.20200217

11. Schaub L, Harrabi SB, Debus J. Particle therapy in the future of precision therapy. Br J Radiol 2020; 93: 20200183 . doi: https:// doi.org/10.1259/bjr.20200183
12. Held KD, Lomax AJ, Troost EGC. Proton therapy special feature: introductory editorial. Br J Radiol 2020; 93: 20209004. doi: https://doi.org/10.1259/bjr. 20209004

13. Tunariu N, Blackledge M, Messiou C, Petralia G, Padhani A, Curcean S, et al. What's new for clinical whole-body MRI (WB-MRI) in the 21st century. Br J Radiol 2020; 93: 20200562. doi: https://doi.org/10. 1259/bjr.20200562

14. Pabon-Ramos WM, Raman V, Schwartz FR, Tong BC, Koweek LM. Magnetic resonance lymphangiography of the central lymphatic system: technique and clinical applications. J Magn Reson Imaging 2020;11 Feb 2020. doi: https://doi. org/10.1002/jmri.27069

15. Hounsfield GN. Computerized transverse axial scanning (tomography). 1. description of system. Br J Radiol 1973; 46: 1016-22. doi: https://doi.org/10.1259/0007-1285-46552-1016

16. Gray LH, CongerAD, Ebert M, Hornsey S, Scott OC. The concentration of oxygen dissolved in tissues at the time of irradiation as a factor in radiotherapy. Br J Radiol 1953; 26: 638-48. doi: https://doi.org/10.1259/ 0007-1285-26-312-638 